\title{
The Earliest Law Books of the City of Brno and Their Relation to the Contemporary Legal Practice
}

\begin{abstract}
The essay focuses on an analysis of the earliest law books of the city of Brno with an emphasis on their relationship to contemporary legal practice. Special attention will be paid to the earliest Brno law book (inv. No. 1) and the Law Book of the City of Brno from the middle of the fourteenth century (inv. No. 2), which, despite not having a normative character, were clearly used in legal practice. This use is proven by the textual tradition of the latter law book and its preservation in several redactions that inspired later legal monuments. The second part of the essay starts from an analysis of selected regulations of the Law Book of the City of Brno and their comparison with preserved legal instructions for the town of Uherské Hradiště, which in the Middle Ages and Early Modern Period belonged to the circle of Brno municipal law. Then, on the basis of the aforementioned analysis, the relationship between contemporary practice and the texts of the given law books are evaluated. At the same time, the essay will point to the presence of the ius commune influences in the individual legal instructions.
\end{abstract}

Keywords: municipal law, Brno, legal instructions, Law Book of the City of Brno, Middle Ages

Słowa klucze: prawo miejskie, Brno, pouczenia prawne, Księga prawna miasta Brna, średniowiecze

\section{Introduction}

An investigation of the importance of law books in the life of medieval urban society must begin with a basic analysis of the relationship between norms fixed in writing and the legal practice of the period. Aside from codicological and diplomatic studies, one might verify whether the written norm of the law books really regulated the urban legal situation with a legal-historical comparison of the relevant sources. The present essay takes the latter approach with a comparison of the mid-fourteenth-century Law Book 
of the City of Brno (or the Law Book of Jan the Notary) ${ }^{1}$ with the legal instructions addressed by the Brno sworn men to the town of Uherské Hradiště, ${ }^{2}$ which belonged to the circle of Brno municipal law. Jan's Schöffenbuch, which influenced in a fundamental way the form taken by municipal law in Moravian and Bohemian towns, was not the creation of abstract and sovereign legislation in the modern sense of the word, but a work based on judicial findings and legal instructions, as well as statutory law. These sources reflected the contemporary administration of justice and the conduct of law and grounded the work in the legal practice of the period.

The task at hand, an investigation of the relationship of the Law Book of the City of Brno to the legal practice of the fourteenth and fifteenth century, calls first for the presentation of the various sources from which the aforementioned law book drew. ${ }^{3}$ In this context, it will be necessary to characterize briefly the development of Brno municipal law prior to the creation of Jan's work. The essay will then touch on the earliest legal manuscript of the city of Brno (No. 1) which is regarded the "predecessor" of the Law Book of Jan the Notary. The essay will naturally pay special attention to the Law Book of the City of Brno itself. The textual tradition of the book, as well as the derivation of law books and collections from it, prove an unprecedented interest in its content in the period following its composition and the exceptional role that this book played outside the actual area of the legal circle of Brno. The core of the essay, however, lies in comparison of the Law Book of the City of Brno and the legal instructions addressed by the Brno sworn men to the town of Uherské Hradiště. Therefore, the primary focus will be on the extent to which the Law Book was used within the Brno legal circle. On the basis of the individual cases analysed, the essay will conclude with an assessment of the degree to which legal practice corresponded to the norms contained in the Law Book of the City of Brno and how much it was influenced by the principles of the ius commune.

1 Edition of this significant legal monument, including the commentary, indexes and list of earlier literature was compiled by Miroslav Flodr, see Právní kniha města Brna. I-III, ed. M. Flodr, Brno 1990-1993.

2 The summary of sources and available literature particularly in Chap. 5.

3 The genesis of Brno municipal law from its beginnings to the late fifteenth century was elaborated by Miroslav Flodr, the editor of a series of Brno legal sources. The result of his long-term research is a threevolume monograph mapping individual stages of legal and administrative development of the city of Brno. The first volume of Flodr's trilogy maps the development of Brno municipal law and administration from the time of the foundation of the royal settlement bellow the Brno castle until 1359. At the core of his work is a content analysis of the Law Book of Jan the Notary structured according to particular areas of law. M. Flodr, Brněnské městské právo. Zakladatelské obdobi (-1359), Brno 2001. The second and third volume of Flodr's monograph focus on the period after the publication of the Law Book of the City of Brno. He focused particularly on the sources building on the tradition of the Law Book of Jan the Notary, the development of Brno municipal administration and issuing of legal instructions. See M. Flodr, Brněnské městské právo po smrti notáře Jana (1359-1389), Brno 2006; idem, Brněnské městské právo na konci středověku (1389 konec 15. století), Brno 2008. Earlier, more synoptic works include also the paper by F. Hoffmann, Brněnské městské právo [in:] Brno mezi městy středni Evropy (Sbornik projevů, studií, úvah a sdělení z védeckého sympozia konaného 29.-30. listopadu 1979, eds. F. Zř́́dkaveselý, V. Peša, Brno 1983, pp. 166-180.

Artykuły - Articles 


\section{The legal development of Brno to the middle of the fourteenth century}

The legal development prior to the origin of the Law Book of Jan the Notary is characterized by two major features. First, it was a strong tendency of the sworn men of Brno to use royal privileges to consolidate the basic mass of law which served as a stepping stone for the further development of municipal law. ${ }^{4}$ Another major characteristic of the development was the ability of municipal law to adopt foreign models advisedly and transform them creatively with regards to local needs. ${ }^{5}$ It was this ability which to a certain degree determined the viability and attractiveness of municipal law for other towns that were either inspired by it or applied it directly.

The essay will now focus on the sources used by Jan for his Schöffenbuch as they contain both aforementioned characteristics of the development. The efforts to gradually fix in writing those regulations which should secure the administrative and legal operation of the city of Brno and contribute to the legal security of its citizens is particularly clear in the case of the the privilege of the King Wenceslas I (iura originalia) for the city of Brno from January $1243 .{ }^{6}$ This essential document was later followed by a series of royal privileges from the period of the reign of the Prremyslids and Luxembourgs. ${ }^{7}$ These privileges significantly contributed to reinforcing the proper operation of the municipal administration, to strengthening the economic position of the city and its confidence. The tendency to fix law in writing is as well documented on the example of the earliest modification of municipal law of the city of Brno from the early fourteenth century, which consisted of 77 articles. ${ }^{8}$ This book known and used in the German version is preserved

4 M. Flodr, Brněnské městské právo. Zakladatelské období..., p. 25. This tendency reflecting a deeper transformation of medieval thinking in the thirteenth century was manifested across the whole medieval society and significantly influenced legal status of towns. For a good elaboration of this issue on the example of the city of Augsburg, cf. M.F. Kluge, Die Macht des Gedächtnisses: Entstehung und Wandel kommunaler Schriftkultur im spätmittelalterlichen Augsburg, Leiden-Boston 2014.

5 M. Flodr, Brněnské městské právo. Zakladatelské období.., pp. 81-83. This tendency can be traced in a given era also in other European cities, particularly in relation to the reception of Roman law, cf. e.g. M.A. Mayer, Der Kauf nach dem Augsburger Stadtrecht von 1276 im Vergleich zum gemeinen römischen Recht, Berlin 2009.

6 Codex diplomaticus et epistolaris regni Bohemiae (hereinafter CDB) IV-1, eds. J. Šebánek, S. Dušková, Pragae 1962, No. 17, pp. 79-87. Wenceslas's privilege was drawn under the influence of Babenberg municipal law and the earlier Enns privilege - Urkundenbuch zur Geschichte der Babenberger in Österreich (hereinafter BUB) 2, ed. H. Fichtenau, Wien 1955, No. 237 from 18.10.1221; and BUB 1, ed. H. Fichtenau, Wien 1950, No. 183 from 22.04.1212. The edition of Wenceslas's privilege, including Czech and German translations, was compiled by M. Flodr, see Iura originalia civitatis Brunensis. Privilegium českého krále Václava I. z ledna roku 1243 pro mésto Brno, ed. M. Flodr, Brno 1993. For the characteristic of the privilege see Dějiny města Brna 1, eds. J. Dř́mal, V. Peša, Brno 1969, pp. 43-44; in general L. Sulitková, Vývoj městských knih v Brně ve středověku: (v kontextu vývoje městských knih v českých zemích), Praha 2004, pp. 114-115; also M. Flodr, Brněnské městské právo. Zakladatelské obdobi..., pp. 34-36; most recently in Dějiny Brna 2. Středověké město, ed. L. Jan, Brno 2013, pp. 412-415.

7 These privileges were analysed in detail by M. Flodr, Brněnské městské právo. Zakladatelské období..., pp. 40-46, 50-64, however, without reference to the earlier literature. A synopsis of thereof was compiled by L. Sulitková, Vývoj..., p. 170, Note 21.

8 The edition is accessible in Právni kniha..., I, pp. 442-449. 
in the earliest manuscript No. 1, currently deposited in the Archive of the City of Brno (ff. 220ra-223vb). ${ }^{9}$ The materially amended text of the original laws (iura originalia) acquired a more modern form ${ }^{10}$ under the influence of the Jihlava privilege, ${ }^{11}$ however, it was not a merely mechanical adoption. It considered the changing demands of the legal practice of Brno into which it was effectively integrated. Aside from the fixation in writing it thus shows the latter fundamental tendency of the development of municipal law of Brno - the ability to transform foreign models considering local needs.

This ability can be observed also in statutory law. ${ }^{12}$ However, unlike the well documented evidence of the law granted to the city of Brno by the Bohemian sovereigns, in the case of statutory law there is a considerable lack of preserved sources. ${ }^{13}$ The same applies to the findings of the sworn men of Brno. ${ }^{14}$ The absence of authentic sources in both cases is partially compensated by the relevant records in the Law Book of the City of Brno (manuscript No. 2), which provides not only the collection of preserved statutory texts but also texts of a number of findings. Jan's findings were taken from the lost Book of sentences, which he created at the beginning of 1343 as a complete novelty. ${ }^{15}$ The individual findings and instructions were entered in chronological order in the Book of sentences which recorded the entire legal process from a complaint to the finding. ${ }^{16}$ The importance of Jan's exceptional deed lies in the fact that the formation of the Book of sentences brought order to otherwise uncontrolled and non-systemic recording practice, which was newly regulated by the book (code of law) as the permanent bearer of particular records.

\section{The earliest law manuscript of the city of $\mathrm{Brno}^{17}$}

Aside from creating the aforementioned Book of sentences and shortly after he started working as a city scribe, Jan helped to enforce and implement the idea of introducing other types of municipal books, which Brno had lacked until then, and the purpose of

9 AMB - Archiv města Brna, A $1 / 3$, Sbírka rukopisů a úředních knih, rkp. č. 1, právní sborník města Brna. The original Latin version, which undoubtedly existed, has not been preserved and only later copies are available, cf. Právní kniha..., II, pp. 192-204, including the commentary on 77 articles from this collection.

10 M. Flodr, Brněnské městské právo. Zakladatelské období.., pp. 46-48; and also idem, Brněnské městské právo po smrti notáře Jana..., p. 29.

11 Of the two versions, which are allegedly from 1249, the broader and also later version (B) of Jihlava privilege from about 1290 was used - CDB IV-1, pp. 290-328, No. 177 (B). Právní kniha..., II, p. 194 relativises a supposed strong influence of Jihlava law on Brno law, as assumed by the earlier literature, and acknowledges it only for the period of the early fourteenth century.

12 M. Flodr, Brněnské městské právo. Zakladatelské období.., p. 81.

13 This is the case especially for the second half of the thirteenth century. Idem, Brněnské městské právo. Zakladatelské obdobi..., p. 67.

14 Idem, Brněnské městské právo po smrti notáře Jana..., p. 79.

15 Právni kniha..., I, pp. 47-48; also M. Flodr, Brněnské městské právo. Zakladatelské obdobi..., p. 76; idem, Brněnské městské právo po smrti notáře Jana..., pp. 107-108.

16 Právní kniha..., I, p. 47.

17 AMB, A 1/3, Sbírka rukopisů a úředních knih, rkp. č. 1. The edition is available in Právní kniha ..., I, pp. 450-490. The commentary in Právní kniha..., II, pp. 205-216. 
which was to improve the existing system of municipal documents. The essay will focus on two results of Jan's reformatory efforts to improve the municipal books. ${ }^{18}$ The first result was in the area of the municipal administration, represented by the formation of official books. ${ }^{19}$ The efforts in the court area resulted in the creation of legal guides which were to facilitate the conduct of law. The latter category also includes the earliest legal manuscripts of the city of Brno (No. 1 and No. 2), which will be the subject of the following discussion.

The attention will be paid first to the earliest legal manuscript No. $1 .{ }^{20} \mathrm{~A}$ rather complicated genesis of this document explains the reasons for its creation and the relation to the scribe Jan and his reformatory efforts. ${ }^{21}$ According to the results of the latest research, the manuscript No. 1 consists of two parts of different origin which were bound together after the death of Jan the notary, apparently in the second half of the $1360 \mathrm{~s}^{22}$ The first part (to fol. 215), which was most probably written outside the Brno city chancery in $1353,{ }^{23}$ based on the script used, includes a number of legal texts in German, among which a copy of the Swabian Mirror, the Magdeburg law (Weichbildrecht, ius Magdeburgense), Jihlava municipal and mining law and the so-called Ottokar law (die sog. Ottokarischen Rechte) stand out. ${ }^{24}$ This corpus of foreign laws, representing the

18 Právní kniha..., I, pp. 45-46. The overview, typology, detailed diplomatic and codicological analysis and the edition can be found in the available literature. The range of issues related to municipal books is so extensive that it is not possible to refer to all works. Only those works providing a basic overview of the given issue were selected. The list of municipal books in the Czech lands up to 1526 was compiled by R. Nový, Městské knihy v Čechách a na Moravě, 1310-1526: katalog, Praha 1963, however, he did not include law books. More recently this list was complemented by L. Sulitková, Vývoj..., who provides information also on printed editions of municipal books and the list of earlier literature. The overview of works related to manuscripts of municipal laws was briefly outlined by F. Hoffmann, Soupis rukopisù městských práv $v$ českých zemích [in:] Městské právo v 16.-18. století v Evropě. Sborník př́spěvků z mezinárodní konference uspořádané Právnickou fakultou UK ve dnech 25.-27. záři 1979 v Praze, ed. K. Malý, Praha 1982, pp. 245-256. In relation to Brno cf. also L. Sulitková, Městské úřední knihy z Archivu města Brna, 1343-1619. Katalog. 4 vol., Brno 1998-2003, and other works by the author. The collected works by M. Flodr, which are referred to in footnotes, play significant role in the case of Brno. However, in his synthetic work (cit. in Note 3), Flodr does not refer to relevant literature.

19 For the overview of municipal books initiated by the scribe Jan, see Právní kniha..., I, pp. 46-50.

20 The manuscript was pointed out in E.F. Rössler, Die Stadtrechte von Brünn aus dem XIII. u. XIV. Jahrhundert, nach bisher ungedruckten Handschriften, Prag 1852. The so-called Ottokar law was first published by idem, Über die Bedeutung und Behandlung der Geschichte des Rechts in Österreich, Prag 1847.

21 Právní kniha..., I, pp. 50-55; M. Flodr, Brněnské městské právo. Zakladatelské období..., pp. 72-73.

22 Idem, Brněnské městské právo po smrti notáře Jana..., p. 65.

23 Právni kniha..., I, p. 134, Note 189 does not specify the potential place of origin of the copy. This issue could be better understood by studying legal manuscripts with similar content preserved in the Czech environment.

24 A detailed specification of content, ibidem, p. 50. The manuscript documents spreading of German law to the Czech lands. The Czech literature, however, has not paid sufficient attention to this issue. An exception is the outdated work by J. Haněl, O vlivu práva némeckého v Čechách a na Moravě, Praha 1874. On the contrary, a well elaborated work is B. Mendl, Tak řečené Norimberské právo v Čechách, Praha 1938. A more recent contribution is an unpublished thesis by J. Mareš, Magdeburské právo ve městech severozápadnich Čech v predhusitské době, defended at the Faculty of Arts of Charles University in Prague in 2008, which summarizes the existing Czech and foreign literature. An earlier foreign publication G. Schubart-Fikentscher, Die Verbreitung der deutschen Stadtrechte in Osteuropa, Weimar 1942 was followed up with the project Sächsiche Akademie der Wissenschaften zu Leipzig, whose outcomes represent a new direction of research on the influences of German law in Central Europe, cf. e.g. Schwabenspiegel-Forschung im Donaugebiet. 
collection of subsidiary legal sources, was copied from the initiative of Jan, who was most probably aware of the absence of a similar collection available for the sworn men of Brno. In relation to the economic boom of the city and its political accomplishments in the 1340s, the circle of clients requiring legal services from Brno was expanding. The sworn men were thus coming more often into contact with persons belonging to foreign legal circles. Therefore, acquiring copies of paradigmatic texts, which were considered the basis of municipal law used in the Czech lands, was seen by Jan as a step in the right direction.

Aside from that, Jan intended to amend the aforementioned collection of foreign laws with the summary of the existing law of the city of Brno. This summary is currently found in the second part of the manuscript No. 1 (ff. 217-240), which again is divided into two parts. The first, earlier volume of the second part from the early 1330s can be attributed to the notary Jindřich, Jan's predecessor in the position of a municipal notary. The main part consists of the privileges of the Bohemian sovereigns, the most significant being the privilege of Wenceslas I from 1243. The collection of privileges is complemented by the earliest amendment of Brno municipal law from the early fourteenth century with 77 articles,${ }^{25}$ to which the notary Jindřich attached other legal texts representing the earliest summary of the foundations of Brno municipal law. ${ }^{26}$ The second, later volume of the second part is clearly from the period when Jan worked as the notary of the city of Brno. ${ }^{27}$ It contains statutes, findings and legal instructions of the sworn men of Brno, the earliest from the late 1320s..$^{28}$

The entire second part of the manuscript No. 1 shows Jan's pragmatic reasoning. Since at that time he did not yet plan to create a complex collection of Brno municipal law, he used only the part created in the previous era by the notary Jindřich, adding his own collection of findings, statutes and instructions, which he translated to German. As proven by the later manuscript No. 2, Jan's ambitions were undoubtedly greater since they resulted in the creation of his own law book. The earliest legal manuscript No.1 thus represented a significant step on the way to the creation of the Law Book of the City of Brno. ${ }^{29}$ Not only this manuscript foreshadowed a new direction of Jan's thoughts, which

Konferenzbeiträge in Szeged zum mittelalterlichen Rechtstransfer deutscher Spiegel, ed. E. Balogh, BerlinBoston 2015; or the publication I. Bily, W. Carls, K. Gönczi, M. Lazar, Sächsisch-magdeburgisches Recht in Tschechien und in der Slowakei. Untersuchungen zur Geschichte des Rechts und seiner Sprache (= IVS SAXONICO-MAIDEBVRGENSE IN ORIENTE, 5), which is to be published in this following year.

${ }^{25}$ See the text above.

26 For details see Právní kniha..., I, p. 53.

27 The exact date of his tenure cannot be specified. Ibidem, p. 41. Jan held the post of municipal notary between 1340 s and 1350 s.

28 Ibidem, p. 54.

29 M. Boháček, Einflüsse des Römischen Rechts in Böhmen und Mähren, Mediolani 1975, p. 155 argues (however, without giving examples) that to formulate his commentaries, the scribe Jan sometimes used texts from the Swabian or Saxon Mirror. Miroslav Flodr did not study the influences of German law in the Law Book of Jan the Notary and he also did not pay particular attention to the relation between the manuscript No. 1 and No. 2. Although there are cases when the identical text of a finding can be found in both manuscripts (cf. e.g. Právní kniha ..., I, pp. 293-294, No. 438; and ibidem, p. 486, E 36), it does not imply that Jan drew from the manuscript No. 1. Regarding the findings, it is likely that Jan drew from the lost Book of sentences. Both issues require further research. 
were focused on improving the existing legal system, ${ }^{30}$ but at the same time it was an opportunity to discover its limits.

\section{Law Book of Jan the Notary ${ }^{31}$}

At the early 1350s, when Jan began to focus intensively on the issue of how to make the process of finding the law more effective, he was naturally confronted with the limits of the existing legal system of Brno municipal law. An especially complicated situation occurred in the everyday practice of sworn men, when they tried to trace amongst the immense number of earlier findings the one providing the solution of a similar case. Orientation in a text was significantly complicated not only by the extent of legal material, but also by its factual fragmentation. In the upshot, it was the decision-making activity itself that hindered the work of sworn men. These otherwise experienced practitioners were not able to produce a thorough analysis of more complex cases based on particular regulations of the law and its interpretation as they lacked basic legal education and were often illiterate. In such moments, sworn men naturally expected help from the municipal notary. ${ }^{32}$ Jan was willing to meet these expectations. Therefore, his aim was nothing less than a guidebook which would unify the existing mass of law and at the same time satisfy the demands of sworn men as discussed above. ${ }^{33}$

However, to achieve the final form of his book, Jan had to have a clear concept ${ }^{34}$ and schedule his preparatory work. In the first stage, it was necessary to make a revision of all available sources of municipal law: granted, statutory, customary law, and of the findings. Following this revision, Jan made copies of the privileges which were used in practice, and provided them with head abstracts with information on the legal content of the related regulations. ${ }^{35}$ Another step was the excerption of available sources and selection of typical examples, which best represented a particular legal issue. For this part, Jan drew a large number of findings and instructions from the aforementioned lost Book of sentences. ${ }^{36}$ Although the question in which cases Jan proceeded from the actual findings and where he relied on the ius commune or foreign law ${ }^{37}$ will never be easy to answer, the thematic division of the book shows the diversity and extensiveness of the legal pro-

30 Ibidem, pp. 54-55.

31 AMB, A 1/3, Sbírka rukopisů a úředních knih, rkp. č. 2, rukopis Právní knihy. The description of the manuscript including the list of contents in Právni kniha..., I, pp. 90-121. The edition of the law book. Ibidem, pp. 141-440.

32 Ibidem, p. 56.

33 In this respect, Jan's activities were not exceptional. In case of municipal notaries, these activities are well-documented in other works, cf. E. Isenmann, Die deutsche Stadt im Mittelalter (1150-1550), WienKöln-Weimar 2014, esp. p. 422. In the Note 792, the author states further literature related to qualification of municipal notaries. This issue is pursued, with the use of sources of German origin; also by G. Burger, Die südwestdeutschen Stadtschreiber im Mittelalter, Böblingen 1960, pp. 52-63.

34 For more details see Právní kniha..., I, pp. 58-61.

35 Ibidem, p. 75.

36 Ibidem, p. 76 argues that over $70 \%$ of adopted cases were dealing mostly with issues outside Brno.

37 M. Flodr, Brněnské městské právo. Zakladatelské období.., p. 65. 
duction of municipal courts in the Luxembourg era. As soon as he gathered the essential material, Jan began the elaboration of his own law book between 1355 and 1357. ${ }^{38}$ The structure of the book based on alphabetically arranged thematic parts in the manner of legal guides of canon law, was mainly to ensure an easy orientation for the reader. ${ }^{39}$ The actual core of the Law Book of the City of Brno was preceded by the text of the original laws (iura originalia). Other privileges were included at the end following the considerable number of 716 articles. ${ }^{40}$

Although privileges were at the top of the hierarchy of norms, and not findings, the practice often required use of foreign laws, particularly where it was not possible to decide a disputable case on the basis of domestic written or customary law. In such cases it was no exception, and Jan supported this trend, to turn to the ius commune. ${ }^{41}$ However, the ius commune did not become the means for a systematic amending of the Law Book of the City of Brno. Based on his own experience, Jan only did so where he saw limits in domestic law, particularly with potentially urgent issues. ${ }^{42} \mathrm{We}$ can find the use of the ius commune also in Jan's commentaries accompanying selected findings. Since sworn men often relied on the notary's clarification of more complex cases, Jan decided to add his legal interpretations to approximately a quarter of the findings. ${ }^{43}$

38 Právni kniha..., I, p. 55.

39 Compared to the earlier research, Právní kniha..., I, p. 61, esp. Note 202 and pp. 64-65 proved that Jan used alphabetical categorization only in the Law Book of the City of Brno, and for purely practical reasons, not as an expression of his personal preference of alphabetical order. Flodr did not identify the particular guide, since he did not find it essential for understanding Jan's system. Nevertheless, he offers a comparison of the Law Book of the City of Brno with the then widespread guide Summa Monaldi. The earliest memorial book is also organised alphabetically, however, again it was not Jan's intention. The edition and commentary of the memorial book was compiled by M. Flodr, see Pamětní kniha města Brna z let 1343-1376 (1379), ed. M. Flodr, Brno 2005.

40 Idem, Brněnské městské právo. Zakladatelské období..., pp. 73-74.

41 This principle is stated in the Art. 561 in the Law Book of the City of Brno (section: Differencia inter privilegium et ius commune) and Art. 609 (section: Item de successionibus regule speciales et generales). Právní kniha..., I, pp. 340 a 357. On the nature of the ius commune cf. at least an apt description by P. Grossi, A History of European Law, Malden 2010, pp. 29-31; and the latest works M. Bellomo, Europäische Rechtseinheit. Grundlagen und System des Ius Commune, München 2005; T. Repgen, Ius Commune [in:] Usus modernus pandectarum: Römisches Recht, Deutsches Recht und Naturrecht in der Frühen Neuzeit, eds. H.P. Haferkamp, T. Repgen, Köln-Weimar-Wien 2007, pp. 157-173; and the proceedings The Creation of the Ius Commune: From Casus to Regula, eds. J.W. Cairns, P.J. du Plessis, Edinburg 2010. Further literature, particularly Italian, is summarized in M. Bellomo, The Common Legal Past of Europe: 1000-1800, Washington, DC 1995, pp. 237-240.

42 Právni kniha..., I, p. 85. A Roman law analysis of the Law Book of the City of Brno can be found mainly in the earlier literature, cf. M. Boháček, Římské právní prvky v právni knize brněnského písaře Jana, Zvl. otisk práce ze semináře Českého práva na Karlově univerzitě v Praze (No. 9), Praha 1924; idem, Ještě k řimskoprávnimu obsahu brnénské právni knihy [in:] Sborník praci z dějin práva československého, sv. I. (K 50. narozeninám profesora Jana Kaprasa jeho žáci), Praha 1930, pp. 34-49. G. Schubart-Fikentscher, Das Brünner Schöffenbuch. Beiträge zur spätmittelalterlichen Rechts-und Kulturgeschichte, "Deutsches Archiv" 1937, vol. 1, pp. 457-498; eadem, Das Eherecht im Brünner Schöffenbuch, Stuttgart 1935; eadem, Neue Fälle zum Brünner Recht, "Deutsches Archiv" 1939, vol. 3, pp. 430-496; eadem, Römisches Recht im Brünner Schöffenbuch: Ein Betag zur Rezeptionsgeschichte, "Zeitschrift der Savigny-Stiftung für Rechtsgeschichte. Germanistische Abteilung” 1947, vol. 65, pp. 86-176.

43 Právní kniha..., I, p. 87. 
The development of Brno municipal law, ${ }^{44}$ however, did not end with the death of the scribe Jan, who did not live to see the active use of his work. ${ }^{45}$ It is proven not only by the rich textual tradition of the Law Book of the City of Brno including its numerous redactions, the publication in 1497 or later Czech and German translations and also further law books and collections derived from it. ${ }^{46}$ To follow this visible mark, which Jan left in the legal development of Moravian and Bohemian towns from the moment of the creation of his book would require a separate essay. Therefore, this brief excursion will be concluded with partial insights related to the development of Brno municipal law to the middle of the fourteenth century.

The earlier stage of the development of Brno municipal law, characterized by the prevalence of customary law, legal particularism and gaps in the legislation, was replaced by the prevalence of written law. The most significant result of this tendency to fix in writing the foundations of its legal and administrative independence was Wenceslas's privilege from 1243 followed by a series of privileges of the Přemyslid and Luxembourg sovereigns. The second characteristic of Brno municipal law related to its openness to various foreign laws could be seen on several levels. The tendency to use the ius commune, the effort to creatively modify foreign models with regards to current local needs, and the willingness to provide legal instructions to foreign applicants. All this contributed to the successful development of the Brno legal circle and the reputation of the city as an experience practitioner and creator of law. These levels were also reflected in the Law book of Jan the Notary. The preserved legal instructions, which are the subject of discussion in the second analytical part of the essay, testify to the intensive relations developed among Brno as the supreme court of appeal and other Moravian towns. To better understand the position of law books in the life of medieval society, the essay will on the example of comparison of selected legal instructions for the town of Uherské Hradiště attempt to answer a more general question to what extent the legal practice corresponded with the norms contained in the Law Book of Jan the Notary and also how much it was influenced by the common law (ius commune).

${ }_{44}$ This later development is mapped in detail by M. Flodr. Ibidem and idem, Brněnské městské právo na konci středověku... See also some earlier works, e.g. J. Štěpán, Ke krystalizačnímu procesu městského práva českého [in:] Mèstské právo v 16.-18. století v Evropě. Sborník př̀spěvki̊ z mezinárodni konference usporádané Právnickou fakultou UK ve dnech 25.-27. zář́ 1979 v Praze, ed. K. Malý, Praha 1982, pp. 267-277; or M. Boháček, Římské právo v právním vývoji českých zemí [in:] Antika a česká kultura, ed. L. Svoboda, Praha 1978, esp. pp. 197-199, 202-204, which sees the development from the viewpoint of the reception of Roman law.

45 Idem, Brněnské městské právo po smrti notáre Jana..., pp. 30-34.

46 One of the law books derived from the Law Book of the City of Brno is e.g. Manipulus vel directorium iuris civilis, the modern critical edition of which was compiled by M. Flodr, see Jan z Gelnhausenu. Príručka práva městského: (Manipulus vel directorium iuris civilis), ed. M. Flodr, Brno 2008. 


\section{Legal practice of the city of Brno using the example of legal instructions of the city of Brno for the town of Uherské Hradiště}

\subsection{The role of legal instructions in the applied practice of the so-called legal circle of Brno}

The territory, which was by virtue of royal privileges governed by the law of the city of Brno, is called the Brno legal circle. The boundaries of this legal circle were changing during the late Middle Ages and Early Modern Period. The sources show several dozen localities, which at that time maintained frequent legal contact with Brno. ${ }^{47}$

Although the legal circle of Brno fell teritorially in the southern German legal area, from the second half of the fourteenth century the subordination was merely formal. This fact is illustrated on the privilege of the Moravian Margrave Jan Jindrich from December 21, 1350, which strengthened the legal position of Brno both on domestic and international level. The privilege specified that the towns and villages which fell under the administration of the Měnín municipal law, ${ }^{48}$ were required to address all appeals exclusively to Brno. The privilege also stated a ban to appeal to foreign institutions and to adopt their legal instructions, as had previously been the custom in some of the cases. ${ }^{49}$ The aforementioned privilege granted Brno the authority of the supreme court

47 The characteristic of the legal circle of Brno, its transformations and the state of preserved Brno legal instructions have been studied by Ivan Štarha. Of his works, two fundamental studies dealing with the territorial delimitation of the legal circle of Brno are referred to, see I. Štarha, Okruh brněnského městského práva [in:] Brno mezi městy středni Evropy - Sborník projevů, studií, úvah a sdělení z vědeckého sympozia konaného 29.-30. listopadu 1979, eds. F. Zř́́dkaveselý, V. Peša, Brno 1983, pp. 138-165; idem, Okruh brněnského městského práva v době předbělohorské, "Brno v minulosti a dnes” 1966, vol. 8, pp. $172-188$. Aside from this, another essential reference is Štarha's work focusing on issuing of Brno legal instructions in the pre-White Mountain period, see I. Štarha, Právní naučení brněnského městského práva v době predbělohorské, (Dissertation), Brno 1970; and the preceding partial study published in the periodical "Folia Diplomatica", see idem, Naučeni brněnského městského práva v 16. a poč. 17. stol., "Folia Diplomatica" 1956-1957, Vol. 5, pp. 207-215.

48 Měnín is a village located $14 \mathrm{~km}$ southeast of Brno. At the beginning of the fourteenth century, due to its advantageous location, the village was still an important centre situated on a major traffic route connecting Moravia and Austria, the legal system of which was binding for a number of villages lying in the southern part of the present Brno-venkov District. A certain decline of Ménín occured in the 1330s, when the Bohemian King John of Luxembourg issued the charter, which mandated that traders arriving to Moravia from Austria must travel via Brno, not Měnín. The charter is made accessible in the edition Codex diplomaticus et epistolaris Moraviae VI (hereinafter CDM), ed. J. Chytil, Brünn 1854, p. 355, n. 465. More on this issue in R. Vermouzek, Brno - křižovatka starých cest [in:] Brno mezi městy střední Evropy - Sborník projevi̊, studii, úvah a sděleni z vědeckého sympozia konaného 29-30 listopadu 1979, eds. F. Zř́ídkaveselý, V. Peša, Brno 1983, p. 188.

49 From the text of the aforementioned charter, cf.: [...] Sane cum ab olim opidani in Meneis [Měnín] fideles nostri dilecti ex quadam turpi consuetudine et quodam more illaudabili iura causarum suarum iudiciariarum super quibus dubium incidebat in alienis partibus in vituperium terre nostre tanquam in ea loca insigniora non existant, ad que recurrerent in hac parte et nonnulli alii opidani et villarum inhabitatores et incole in eodem opido Meneis similiter iura sua locis terre nostre spretis nobilioribus in quibus copia sapientum existit, querere, recipere usque ad hec tempora consueverunt et tenere eadem... Statuimus et 
of appeal and its decisions were considered definitive. This regulation was to prevent the arbitrariness of South Moravian villages to appeal to institutions located outside the Brno legal circle and thus evade the jurisdiction entrusted to Brno municipal council and the municipal court.

The source base of Brno municipal law, as discussed earlier in more detail, was at that time formed mainly by royal privileges, statutes of the city council and law books, i.e. the earliest law book (the so-called Jindřich's) and later the Law Book of Jan the Notary. Nevertheless, it included also legal customs and Roman law in the form of the ius commune, which was a subsidiary law, thus generally applicable where the domestic legal system showed undesirable gaps. However, considering that the individual municipalities also had their own territorially limited legislation, it frequently occurred that local sworn men were not able to decide the presented case unequivocally and so they turned to Brno with requests for legal instructions. The received legal instructions were later copied into special books or memorial books in the municipal chanceries. The agenda kept in this way served as a binding background material for deciding analogical cases in future.

Requests for legal instructions were addressed to the Brno municipal council (concilium civitatis), which consisted of twelve old and twelve new sworn men (iurati, or iurati cives) ${ }^{50}$ who were in principle respectable Brno burghers, usually representatives of prominent patrician families, with at least basic knowledge of the legislation. However, the sources imply that in the early 1360 s the council consisted also of craftsmen and wealthy merchants, who were not originally from Brno. ${ }^{51}$ Among other competences, sworn men had a judicial authority to issue findings (judgments). They shared this authority with the reeve (iudex, in German, Richter), who represented the sovereign

sancimus quatenus precipue dicti opidini et opidani in Meneis [Měnín] et deinde in Auspicz [Hustopeče], Pohorlicz [Pohořelice], Eyvanczicz [Ivančice] et aliorum opidorum et villarum inhabitatores et incole, qui in dicto opido Meneis [Měnín] iura sua recipere hactenus consueuerunt ex nunc in antea perpetuis temporibus successuris iura et sentencias causarum iudiciariarum, super quibus deinceps dubium ortum fuerit, apud ipsos in civitate nostra Brunensi in qua copia sapientum exsistit et quam inter ceteras civitates terre nostre, cum sine ipsa ipse alie civitates nostre essent quasi acephale, interne dileccionis affectu prosequimur, querere recipere eisque regi sine renitencia teneantur [...]. CDM VIII, ed. V. Brandl, Brünn 1874, pp. 29-30, No. 60. The text of Jan's privilege is made accessible also in Právní kniha ..., I, pp. 414-415.

50 A total number of twenty-four sworn men, who formed the so-called broader council, is mentioned also in the privilege of Wenceslas I from 1243 in Art. 16 De potestate iuratorum, where the competences of this authority are specified. Cf. text of the aforementioned regulation: XXIIII civium iurati de mercatu et aliis, que ad honorem et utilitatem pertinent civitatis, pro ingenio suo debeant fideliter ordinare, quorum ordinacionem nec iudex nec cives nec alter quispiam irritabit; quod qui presumpserit attemptare, solvat iudici penam eisdem statutam. Právni kniha..., I, p. 147. The issue of electing sworn men in the office is discussed in a separate privilege of Wenceslas II from 1292, known as Privilegium de eleccione iuratorum. On the text of the privilege see Právní kniha ..., I, pp. 402-403. H. Jordánková and L. Sulitková, who have been systematically focusing on the issue of Brno municipal administration in the Middle Ages and the Early Modern Period (concentrating mainly on pre-White Mountain era), pointed out that the model of electing Brno sworn men did not correspond with the Austrian or German model and was based on a different concept. More on this issue in H. Jordánková, L. Sulitková, Fungováni nejvy̌šsího městského správního orgánu ve světle pamětnich zápisů městských písař̀ na přikladu raně novověkého Brna [in:] Pragmatické písemnosti $v$ kontextu právním a správním, eds. Z. Hojda, H. Pátková, Praha 2008, pp. 148-150.

51 D. Janiš, Městská správa a soudnictví [in:] Dějiny Brna 2. Středověké město, ed. L. Jan, Brno 2013, p. 427. Similar requirements for Brno sworn men were applied to sworn men in German towns. On this issue, cf. E. Isenmann, Die deutsche Stadt..., esp. pp. 350-352, in wider context pp. 327-386. 
and thus held a rather representative function. ${ }^{52}$ The main administrative task of sworn men was finding the law and providing legal instructions. This required a certain knowledge of sources of Brno municipal law and the ability to apply instructions in practice. Although legal education was required for this office, due to the lack of suitable candidates, it was often sufficient for applicants to have a practical knowledge of law and administration, which they acquired in a previous position. Therefore, in cases where they lacked personal experience, sworn men could consult the city notary. ${ }^{53}$ The preserved collection of Brno legal instructions may provide important information not only of the nature of solving disputes, but also to a professional standard of officials dealing with requests for legal instructions. Given the rich source base, the results of this research will be demonstrated on the selected legal instructions for the town of Uherské Hradiště, which was the first ever recipient of Brno legal instructions.

\subsection{Uherské Hradiště as the recipient of Brno legal instructions}

The founding town which joined the Brno legal circle was Uherské Hradiště. It happened on 23 May, 1258 by virtue of the charter of the King of Bohemia Přemysl Otakar II, who granted Brno municipal law to the town of Uherské Hradiště and at the same time obliged the town to address requests for legal instructions to Brno. ${ }^{54}$ Uherské Hradišš requested legal instructions from Brno regularly until 1472, when the town was freed from this obligation based on the privilege of the King Władysław, which the people of Uherské Hradiště received for their loyalty in the war with Matthias Corvinus. Despite this fact, legal cooperation of the two cities was renewed in the early 1480s and Uherské Hradiště, which at that time formed its own legal circle with a large number of subordinate localities, again requested legal instructions from Brno. ${ }^{55}$

Important information about legal contacts of the city of Brno with the town of Uherské Hradiště is provided by the Law Book of Jan the Notary. The casuistic regula-

${ }_{52}$ For more details on competences of a reeve in High and Late Medieval Brno see D. Janiš, Úřad rychtáře a městská jurisdikce v Brně ve 13. a 14. století. 1. část, zakladatelské období, "Brno v minulosti a dnes" 2012, vol. 25, pp. 33-49; idem, Úřad rychtáŕe a městská jurisdikce v Brně ve 13. a 14. století. 2. část, obdobi rozvoje města, "Brno v minulosti a dnes" 2013, vol. 26, pp. 11-25.

${ }_{53}$ A typical example is the notary Jan, the author of the Law Book of the City of Brno, who probably obtained his legal education at a university. On this issue, see particularly M. Flodr, Cesta k právu a spravedlnosti. Jan, notár města Brna [in:] Osobnosti moravských dějin, eds. L. Jan et al., Brno 2006, pp. 89-102. On the issue of the level of education in Czech towns, cf. proceedings Město a intelektuálové od středovéku do roku 1848: Sborník statí a rozšiřrených přispěvků z 25. vědecké konference Archivu hlavního města Prahy, uspořádané ve spolupráci s Institutem mezinárodnich studii Fakulty sociálnich věd Univerzity Karlovy v Praze ve dnech 10. až 12. ř́jna 2006 v Clam-Gallasově paláci v Praze, eds. O. Fejtová, V. Ledvinka, J. Pešek, Praha 2008. For the German environment, cf. proceedings Gelehrte im Reich zur Sozial- und Wirkungsgeschichte akademischer Eliten des 14. bis 16. Jahrhunderts, ed. R.Ch. Schwinges, Berlin 1996. In a broader context cf. the main results of the research project „Medieval Urban Literacy“, esp. Writing and the Administration of Medieval Towns: Medieval Urban Literacy I, eds. M. Mostert, A. Adamska, Turnhout 2014; and Uses of the Written Word in Medieval Towns: Medieval Urban Literacy II, eds. M. Mostert, A. Adamska, Turnhout 2014.

54 Cf. text of the relevant instruction: Item volumus et mandamus, ut civitas ipsa eo fundaretur iure et gauderet perpetuo, quo civitas Brunnensis fundata videtur vel gaudere. CDB V-1, eds. J. Šebánek, S. Dušková, Pragae 1974, pp. 245-248, No. 156.

55 I. Štarha, Okruh brněnského městského práva ..., p. 178.

Artykuły - Articles 
tions in the book give evidence on the contents of the lost Book of sentences..$^{56} \mathrm{~A}$ total of thirty cases reflecting the disputes solved in the first half of the fourteenth century are preserved for Uherské Hradiště. ${ }^{57}$ Two municipal books kept by the town of Uherské Hradište were significant for the period after the completion of the Law Book of the City of Brno. Both manuscripts contain a few hundred instructions of civil and criminal law, which Uherské Hradiště received between 1368 and 1540. The earlier manuscript, Liber negotiorum civitatis Hradisch, which served as a memorial book, contains a collection of legal instructions written mainly in Latin between 1368 and $1389 .{ }^{58}$ The later manuscript, formed in the late first half of the fifteenth century, recorded legal instructions received between 1447 and 1509, including the addenda until $1540 .{ }^{59}$ With a few exceptions, the manuscript was written in old Czech.

In connection with such an extensive preserved agenda, the question naturally arises to what extent the legal instructions from the Liber negotiorum civitatis Hradisch and Liber informationum et sententiarum corresponded with the legal regulations from the Law Book of Jan the Notary, which, despite not having a normative character, played

56 Although the Book of sentences from Brno has not been preserved and thus it is not possible to compare both sources, the current legal-historical literature more or less agrees that the cases presented here really occured and are not fictitious findings. The opposite opinion was presented by František Čáda, who argued that the case in the Art. 520 (according to the earlier Rössler edition Art. 536) related to the murder of a newborn, was made up by the notary Jan for the needs of his book. See F. Čáda, Sententia Brunnensie 536 [in:] Sbornik k poctě šedesátých narozenin Jaroslava Kallaba, ed. K. Engliš, Praha 1939, pp. 63-75. This thesis was definitely disproven in the 1990s by M. Flodr, see Právní kniha..., II. Komentár̆, Brno 1992, p. 138. Most recently see N. Štachová, Inspirační zdroje Koldínových Práv městských. Výzvy kodikologie české romanistice, “Časopis pro právní vědu a praxi” 2013, Vol. 21 (supplementum), pp. 262-269.

57 Therefore, in terms of the number of legal instructions contained here, Uherské Hradiště is one of the most represented localities in the Law Book of Jan the Notary. Although this type of source can provide a valuable evidence of everyday life in Moravian medieval society, legal instructions from the remaining localities contained in the Law Book of Jan the notary have been neglected by the literature, with the exception of the paper by Jiří Doležel, who dealt with the issue of legal instructions for the town of Tišnov. On that see J. Doležel, Tišnov a Tišnovští v právni knize města Brna z poloviny 14. století, "Sborník Okresního muzea Brno - venkov" 2000, pp. 7-29.

58 The municipal book for Uherské Hradiště Liber negotiorum civitatis Hradisch was published in two editions. The first part of the manuscript, which contains various memorial records and copies of municipal statutes and privileges was made accessible in the edition by Magdalena Čoupková, see Nejstarši uherskohradišt'ská městská kniha. Liber negotiorum civitatis Hradisch, ed. M. Čoupková, Uherské Hradiště 2001. The publication of the edition was preceded by her paper with a brief description of the source. Cf. eadem, Nejstarši uherskohradišt'ská městská kniha. Liber negotiorum civitatis Hradisch [in:] Středověká města na Moravě a v sousedních zemích, ed. P. Futák, M. Plaček, M. Vařeka, Hodonín 2009, pp. 11-21. The second part of the manuscript, containing legal instructions for the town of Uherské Hradiště, was published later in an edition by M. Flodr. The edition includes a commentary, which introduces contents of particular legal instructions. Nálezy brněnského městského práva. Svazek I. (-1389), ed. M. Flodr, Brno 2007, pp. 13-76. The relation between legal instructions contained in the Liber negotiorum civitatis Hradisch and the Law Book of Jan the Notary was earlier studied by Ivan Krška, who proved that legal instructions in both sources do not correspond to one another and thus excluded the possibility that some of the findings recorded in the law book were later adopted into Uherské Hradiště manuscript. For more on that see I. Krška, Brněnská právní naučeni Uherskému Hradišti ve druhé polovině 14. století, "Brno v minulosti a dnes" 1962, vol. 4, pp. 200-209.

59 The book of legal instructions Liber informationum et sententiarum was made accessible in an edition in the second half of the nineteenth century thanks to Ignác Tkáč, see Liber informationum et sententiarum čili Naučeni Brněnská Hradištské městské radě dávaná od roku 1447 až do roku 1509 s dodatky do roku 1540, ed. I. Tkáč, Uherské Hradiště 1882. 
an essential role in the applied practice, for which it was intended..$^{60}$ In relation to this, considering the noticeably Romanized content of the Law Book of the City of Brno, the question arises whether the ius commune influences could penetrate the content of legal instructions, either in the form of individual principles or in the form of verbatim quotations. ${ }^{61}$ The answer to these questions could explain the role of law books in the life of medieval and early modern society and at the same time discover how much the formal reception of Roman law ${ }^{62}$ was reflected in the legal practice. ${ }^{63}$ This issue, demonstrated on the example of the relation of the Law Book of the City of Brno and selected legal instructions for the town of Uherské Hradiště, will be analysed in the following subchapter.

Although both manuscripts contain a rich agenda of disputes related to particular areas of legal life of medieval society, it was necessary to select only those legal instructions applicable for this research that would lead to accomplishing the above set goals. The reason for that is the fact that a number of legal instructions do not have a sufficient

60 The research has been dealing with this issue only partially. As was already mentioned, M. Flodr, who made part of the manuscript Liber negotiorum civitatis Hradisch accessible in an edition, provided a commentary for individual records (legal instructions). The commentary includes references to the sources of Brno law, particularly the privilege from 1243 and the Law Book of the City of Brno. Cf. Nálezy brněnského městského práva..., pp. 90-123.

${ }^{61}$ The issue related to possible Roman law influences (i.e. the ius commune) in Brno legal instructions for the town of Uherské Hradiště was discussed earlier on the example of a justifiable absence at court hearings (causa absentiae). Based on an analysis of several legal instructions, the conclusion was made that the justifiable reasons for an absence, as stated in the Law Book of the City of Brno, and at the same time corresponding to the Roman law sources, also appeared in the argumentation part of particular legal instructions. It was thus proven that the legal regulations included in the Law Book of the City of Brno were also applied in practice. See L. Šmídová Malárová, “Causa legittimae absentiae” a její řmskoprávní základ $v$ naučeních brněnského městského práva pro Uherské Hradiště [in:] Datum per manus. Přátelé, kolegové a žáci Zbyňku Svitákovi k 60. narozeninám, eds. L. Führer, I. Musilová, J. Voborný, R. Červená, Brno 2015, pp. 147-160. Cf. also L. Šmídová Malárová, K významu právních naučení města Brna z perspektivy právní romanistiky [in:] Bibliotheca antiqua 2015. Sborník z 24. konference dne 4-5 listopadu 2015, eds. R. Krušinský, T. Vintrová, Olomouc 2015, pp. 27-31.

62 On the reception of Roman law, cf. at least selectively W. Trusen, Anfänge des gelehrten Rechts in Deutschland. Ein Beitrag zur Geschichte der Frührezeption, Wiesbaden 1962; P. Koschaker, Europa und das römische Recht, 4. Aufl. München 1966; H. Coing, Handbuch der Quellen und Literatur der neueren europäischen Privatrechtsgeschichte. Bd. I: Mittelalter (1100-1500). Die gelehrten Rechte und die Gesetzgebung, München 1973; H. Lange, M. Kriechbaum, Römisches Recht im Mittelalter, Bd. I.: Glossatoren, München 1997; H. Lange, M. Kriechbaum, Römisches Recht im Mittelalter, Bd. II.: Kommentatoren, München 2007.

63 The subject of interest of domestic Romanistic literature is mainly in the area of the study of normative sources, whereas the issue of applying Roman law (i.e. the ius commune) in legal practice, not only in medieval municipal law, has been somewhat neglected. An exception is the paper by Miroslav Boháček focusing on the application of the rules of Roman-canonical process in the church environment of the Czech lands in the High Middle Ages. M. Boháček, Das Römische Recht in der Praxis der Kirchengerichte der böhmischen Ländern im XIII. Jahrhundert, "Studia Gratiana" 1967, vol. 11, pp. 273-304; and the work by the same author on Roman law formulas in the domestic diplomatic material: M. Boháček, Řimské právo v listinné praxi českých zemi 12. - 15. století, "Sborník archivních prací” 1974, vol. 24, no. 2, pp. 461-486. Nad’a Štachová, who studied the Roman legal terminology in the Bohemian charters from the $13^{\text {th }}$ century, later built on this study. N. Štachová, Obligační právo ve svétle českého diplomatického materiálu 13. století [in:] Naděje právní vědy. Býkov 2010, ed. V. Knoll, Plzeň 2011, pp. 139-150. The work was also published in English, see N. Štachová, Law of Obligations in Light of the Bohemian Diplomatic Documents of the Thirteenth Century, "Journal on European History of Law" 2011, vol. 2, no. 2, pp. 160-164. 
informative value for these purposes. It relates particularly to the cases where the sworn men of Brno provided only a procedural solution, usually in the form of ordering the evidence. It is typical for legal instructions related to disputes arising from relations of obligation (loan receivables, receivables from purchase, etc.), or criminal law disputes, where e.g. an oath on the cross was recommended before the actual announcement of the decision. For this reason, the essay focuses on the choice of a sample of cases which allow to examine the substantive nature of disputes and the particular solution. At the same time, the selection excluded the disputes where, due to the nature of Brno municipal law, the presence of the possible ius commune influences was not expected. Taking these facts into account, a total of six legal instructions were selected, which show in a model way the relation of the Law Book of the City of Brno with the legal practice, and at the same time comply with the received rules of common law (ius commune). These are the cases of acquiring property from a non-owner, implementation of security interests, liability for damage, claims arising from gambling and betting, and the procedural position of the parties.

\subsection{Analysis of selected legal instructions for Uherské Hradiště}

\subsubsection{Acquisition of property from a non-owner}

Both aforementioned books of legal instructions contain only a fractional number of cases dealing with the issue of real property rights (iura in re). The essence of one of the cases is the ban of sale and subsequent purchase from a non-owner, or more precisely from a person who was not authorized for the alienation. It is a rare case, the one of its kind preserved for the town of Uherské Hradiště. The case is documented in the later book of legal instructions Liber informationum et sententiarum. ${ }^{64}$ The request for legal instruction shows that the plaintiff (purchaser) sued the counterparty, who had sold him a house with all the belongings. The sale was to take place in accordance with the regulations of Brno municipal law - the subject of the sale was transferred to the purchaser along with all the belongings, which are further specified in the text of the request for the legal instruction (they were mainly household furnishings). The subject of the dispute was the claim to a small chest with money, which was found in the house. It was not clear whether this chest could be considered a furnishing of the house (i.e. the subject of the sale as a whole), or whether it should be excluded from the sale as such. The main problem consisted in the fact that the owner of the chest and its contents was not the seller but his mother, who apparently did not know about the sale at all. The sworn men of Brno sent a brief legal instruction produced in accordance with the Roman law principle Nemo plus iuris ad alterum transferre potest, quam ipse habet (D. 50.17.54). The purchaser was obliged to return the small chest with money since he was not entitled to sell it. ${ }^{65}$ This principle is not explicitly stated in the Law Book of the City of Brno, however,

64 Legal instruction No. 260 (The sale of a house). Liber informationum et sententiarum ..., pp. $285-286$.

65 Cf. text of the aforementioned legal instruction: Na to vás naučujem, že v tejto při, což jest Matěj svého vlastnieho s domem prodal Janovi Modrému, to má jemu v domu zuostaviti, a což toho po prodaji Matěj vynesl, má to zase Janovi vrátiti a nebo za to podle slušnosti opraviti; ale což Matějovo nebylo, jakožto 
the acquisition of property from a non-owner is regulated by Art. 274. According to this regulation, which was adopted from the Institutiones (I. 2.1.35), the party who acquired property from a non-owner was required to return it. In case the purchaser knew that the seller was not the owner of the property, or that he was not authorized to sell it, a duty of restitution also applied to the fruits consumed, which were subsequently added to the subject of the sale. ${ }^{66}$ What is interesting here is that the relevant regulation of the Law Book of the City of Brno was a verbatim copy from the Institutiones. This was beyond Jan's common practice and his effort to incorporate Roman law regulations into his own interpretation, which in this case is missing. The fact that the regulation was preceded merely by the statement that the decision was made by the sworn men in the town of Skalice (Ad interrogacionem iuratorum de Kalic sentenciatum est) ${ }^{67}$ shows that cases related to this issue were less frequent in the legal circle of Brno and when they were dealt with, the customary law (ius proprium) was absent here. To compensate for gaps in Brno municipal law, the ius commune was applied in such cases. ${ }^{68}$

\subsubsection{Implementation of security interests}

Another case analysed in the essay belongs to the area of encumbrances (iura in re aliena), which is represented more frequently in the preserved sources. The request for a legal instruction concerned the question which of the creditors was to be satisfied first, when both claims were related to the same subject (pledge). This case concerns encumbrances while the question is not related to the area of substantive law but has a purely procedural-legal character. The substance of the dispute rested in the fact that one pledge

truhlice s penězi mateřiny, toho ani žádného cizieho prodati nemohl, aniž moci jměl prodati vedle práva. Ibidem, p. 285.

${ }^{66}$ Cf. Art. 274 of the Law Book of the City of Brno: Ad interrogacionem iuratorum de Kalic sentenciatum est: Si quis a non vero domino, quem dominum esse credebat, bona fide fundum emerit vel ex donacione aliave iusta causa qualibet bona fide acceperit, naturali racione placuit fructus, quos perceperit, eis esse pro cultura et cura. Et ideo, si postea dominus supervenerit et fundum vendicet, de fructibus ab eo consumptis agere non potest. Ei vero, qui sciens fundum alienum possederit, non idem concessum est; itaque eciam fructus cum fundo, licet consumpti sint, cogitur restituere. Právní kniha ..., I, p. 235. Cf. the same regulation in Institutiones (I. 2.1.35): Si quis a non domino, quem dominum esse crederet, bona fide fundum emerit vel ex donatione aliave qua iusta causa aeque bona fide acceperit: naturali ratione placuit, fructus quos percepit eius esse pro cultura et cura. et ideo si postea dominus supervenerit et fundum vindicet, de fructibus ab eo consumptis agere non potest. ei vero qui sciens alienum fundum possederit non idem concessum est. itaque cum fundo etiam fructus, licet consumpti sint, cogitur restituere. The Roman law definition of an acquirer in good faith is included in Manipulus, Art. 941: Bona fidei emptor esse videtur, qui aut ignoravit eam rem alienam esse, aut eum, qui vendidit, putavit ius vendendi habere, puta procuratorem aut tutorem esse. (D. 50.16.109), see Jan z Gelnhausenu. Př́ručka práva městského..., p. 152. On the rules of acquiring property rights from a non-owner see more L. Malárová, Zásada "bonae fidei" a institut nabytí věci od nevlastníka v Přiručce práva městského Jana z Gelnhausenu [in:] Cofola 2011, eds. E. Žatecká, L. Kováčová, J. Horecký, V. Omáčka, Brno 2011, pp. 130-137.

${ }^{67}$ Právni kniha..., I, p. 235. The same opinion is presented by M. Flodr, who argues that the quoted text from the Institutiones represented the key finding in the lost Book of sentences. The text was later adopted by Jan and incorporated into a relevant article of the book and thus represented a case regulation inspired directly by the legal practice. See Právní kniha ..., II, p. 83. Cf. also a brief commentary by G. Schubart-Fikentscher, Römisches Recht..., p. 99.

${ }_{68}$ Cf. M. Černý, Ius commune a ius proprium ve středověku [in:] Metamorfózy práva ve střední Evropě IV.: žijeme v nejlepším z možných právních světů? eds. F. Cvrček, H. Jermanová, Plzeň 2015, pp. 371-372.

Artykuły - Articles 
was the subject of two different security interests (pignus), while the pledge creditors were two different parties. The councillors of Uherské Hradiště were not able to decide the case and sent the request for a legal instruction to Brno with the inquiry whose claim should be satisfied first. ${ }^{69}$ The sworn men of Brno decided the dispute in accordance with the Roman law principle prior in tempore, potior in iure, which is stated in Arts. 551 and 556 of the Law Book of the City of Brno. ${ }^{70}$ The councillors of Uherské Hradiště were thus instructed to satisfy the claim which was submitted first. ${ }^{71}$

The purpose of this principle was to confirm a more favourable position of the creditor, whose claim was of an earlier date than the claim of the other party. In practice it meant that the creditor, whose right to the subject of the pledge (in this case a house) arose earlier, had the right to be fully satisfied from the pledge. This regulation, which later became a general rule in the law of obligations, was also applied in other disputes arising from contractual relations, including claims that were not settled by the security interest. In Corpus iuris civilis the aforementioned principle is stated in the Codex (C. 8.17.3) and Digests (D. 20.4.2), on the basis of which the aforementioned regulation of the Law Book of the City of Brno was formulated. ${ }^{72}$ Gertrud Schubart-Fikentscher points out that the Roman law regulation prior in tempore, potior in iure appears also in the earlier codification of the mining law Ius regale montanorum from the early fourteenth century, however in a different sense not related to the law of obligations. ${ }^{73}$ In the case of Ius regale montanorum, the principle was applied in a situation when two parties requested the same speaker - according to this formula the speaker (advocatus) was assigned to the party who requested it first. ${ }^{74}$

69 Legal instruction No. 228 (Who proves the earlier debt, can claim it). Liber informationum et sententiarum ..., pp. 251-252.

70 Cf. Art. 551 of the Law Book of the City of Brno: Quicumque hereditatem vel pignus aliquod sibi probaverit prius esse obligatum, ille prius suum debitum percipiet pignore de eodem. Dicit enim regula iuris, quod qui prior est tempore, pocior est iure; and see also Art. 556 par. b): Item, si generaliter bona sint obligata et postea res alii specialiter pignori dentur, quoniam ex generali obligacione pocior habetur creditor, qui ante contraxerit, si ab illo priore comparasti, non oportet ab eo, qui postea credidit, inquietari. Právni kniha..., I, p. 337-338. On other parts of the book that incorporated the aforementioned principle, although indirectly see G. Schubart-Fiktenstcher, Römisches Recht..., pp. 95-96.

${ }^{71} \mathrm{Cf}$. text of the aforementioned legal instruction: Na to vás naučujem: Jakož jich viece jmenují se $v$ tomto psanie, kteřiž každý v své při klade, že v svém dluhu ten duom základ maji, že každý ten, ktož tu mluví, že by ten duom byl jeho základ za jeho dluh, má to provésti, a ktož provede starši základ, ten prvé a předkem bud' připuštien z toho se vyvazovati podle práva. Liber informationum et sententiarum..., p. 250.

72 See C. 8.17.3: Si fundum pignori accepisti, antequam rei publicae obligaretur, sicut prior es tempore, ita potior iure. Cf. D. 20.4.2: Qui generaliter bona debitoris pignori accepit eo potior est, cui postea praedium ex his bonis datur, quamvis ex ceteris pecuniam suam redigere possit. Quod si ea conventio prioris fuit, ut ita demum cetera bona pignori haberentur, si pecunia de his, quae generaliter accepit, servari non potuisset, deficiente secunda conventione secundus creditor in pignore postea dato non tam potior quam solus invenietur.

73 G. Schubart-Fiktenstcher, Römisches Recht..., p. 95.

$74 \mathrm{Cf}$. text of the aforementioned regulation in Ius regale montanorum: Sed si duo simul unum petierint advocatum, primus obtineat, juxta illam regulam iuris: Qui prior est tempore, potior est iure. Codex iuris Bohemici: Tomus primus, aetatem premyslidarum continens, ed. H. Jireček, Pragae 1867, p. 382. 


\subsubsection{Liability for damage}

An interesting case from the Romanistic point of view was found among the addenda in Liber informationum et sententiarum. It concerns the contract of purchase, liability for the damage of unclaimed goods and the purchaser's obligation to pay the agreed purchase price for the goods ${ }^{75} \mathrm{~A}$ preserved text of the request for a legal instruction is missing for this case, however, the finding clearly shows that the dispute occured between a brewer (seller) and a purchaser. According to the brief text of the finding, the contract of purchase was concluded (the process of creation of the contract is not specified), nevertheless, the purchaser did not take over the goods (malt) in the prescribed period and left it at seller's premises. Later the question arose how to proceed, when damage occurred during the storage of the already sold goods. The Law Book of the City of Brno amends the issue of transfer of the risk of damage to goods in contracts of purchase in Arts. 285 and 286. According to Art. $285 \mathrm{Sec}$. e) the risk of damage to goods, i.e. liability for damages, which occured to goods after the conclusion of a contract of purchase, transferred to the purchaser at the moment when the contract was concluded. The wellknown Roman law principle periculum est emptoris or periculum pertinet ad emptorem (D. 18.6.8) was applied here, which was reflected in the aforementioned regulation of the Law Book of the City of Brno. ${ }^{76}$ According to this principle, the risk of damage to the goods after the conclusion of a contract of purchase moved to the purchaser, who was liable for the deterioration of the goods. In accordance with this principle, the sworn men of Brno issued an instruction providing the solution how to decide the dispute between the brewer and the purchaser, who did not take immediate delivery of the purchased malt. The text of the legal instruction contains a note that after the conclusion of the contract the seller was not liable for any damage caused to the goods and the buyer was obliged to accept delivery of the malt in such a condition and to pay the fixed purchase price. ${ }^{77}$

75 Legal instruction No. 32 (On malt purchased from a maltster - addendum). Liber informationum et sententiarum..., pp. 380-381. The analysis of this case was published also in L. Šmídová Malárová, K významu právních naučení..., pp. 29-30.

76 Art. $285 \mathrm{sec}$. e) of the Law Book of the City of Brno: Perfecta empcione periculum pertinet ad emptorem. Sed si sub condicione res venditur, tunc si defecerit condicio, nulla est empcio. Právní kniha..., I, p. 239. Cf. D. 18.6.8: Necessario sciendum est, quando perfecta sit emptio: tunc enim sciemus, cuius periculum sit: nam perfecta emptione periculum ad emptorem respiciet. Et si id quod venierit appareat quid quale quantum sit, sit et pretium, et pure venit, perfecta est emptio: quod si sub condicione res venierit, si quidem defecerit condicio, nulla est emptio, sicuti nec stipulatio: quod si exstiterit, Proculus et Octavenus emptoris esse periculum aiunt: idem Pomponius libro nono probat. See also Art. 285 sec. a) of the Law Book of the City of Brno: Si vinum venditum acuerit vel quid aliud vicii sustinuerit, emptoris erit dampnum, sicut si vinum esset effusum vel vasis perforatis vel ligaturis ruptis vel ex quavis alia causa. Právní kniha..., I, p. 238. The rule was taken from the Digest. Cf. D. 18.6.1: Si vinum venditum acuerit vel quid aliud vitii sustinuerit, emptoris erit damnum, sicut si vinum esset effusum vel vasis contusis vel qua alia ex causa. From the literature see G. Schubart-Fikentscher, Römisches Recht..., p. 101.

77 Cf. text of the aforementioned legal instruction: Na to vás n.: Poněvadž spoluměštín váš slad ten s ženú svou u sladovníkủ koupil a na to zavdal, tehdy již jeho slad byl, ale ne sladovníkỉ; by pak i tak bylo, jakož on praví, že tepruov v ponděli vzíti jměl, ale poněvadž že vojsko táhlo, a před tím vojskem to opatřiti mohl a své vzíti a nepobral, tehdy přišel-li jest k jakej škodě, žiadnému o to porokovati nemůže než sám sobě, a dle toho vinovat jest sladovníkóm ten slad zaplatiti. Liber informationum et sententiarum..., pp. 380-381. 


\subsubsection{Claims from gambling and betting}

Another dispute recorded in Liber informationum et sententiarum along with the related request for the issuance of a legal instruction deal with the claim to the money invested in a game. ${ }^{78}$ The case is hence associated with the issue of gambling and betting. The request for the issuance of a legal instruction implies that the dispute took place between two players in a tavern, when one of them was accused of unjustified acquisition of the money invested in the game. It is clear from the claim of one of the parties, who claims in the text of the request that the opposite party took the money without being entitled to it from having won. It is worth noting that the councillors of Uherské Hradiště did not ask whether the winnings from pub gambling and betting were enforceable at all. The question was aimed at procedural law - hence, which of the parties was to prove the claim with relevant evidence. The sworn men of Brno gave the following opinion on the issue - potential winnings from gambling and betting are not enforceable, the question of the procedural character is thus irrelevant. Therefore, the party who took the money was obliged to return it. ${ }^{79}$ Brno municipal law corresponded with the Roman law concept, according to which the winnings from gambling and betting were considered natural obligations (naturalis obligatio). While such obligations formally existed, their satisfaction was not enforceable at the court (Art. 478 of the Law Book of the City of Brno). ${ }^{80}$

A similar case was previously decided in Uherské Hradiště. According to the record in the Liber negotiorum civitatis Hradisch, a dispute arose between two players about money invested in the game of dice and the sworn men of Brno issued a legal instruction, where they were reminded of non-enforceability of winnings from gambling and betting. ${ }^{81}$

78 Legal instruction No. 109 (On the game in a tavern, who takes the money). Ibidem, p. 115.

79 Cf. text of the aforementioned legal instruction: Poněvadž tato pre jde ze hry a práva hry nepotvrzujicí, protož i my hry nesúdíme, ale vzal-li jest Václav Lupa co Majrlovi, jakož tomu neodpírá, povinovat jest to Lupa Majrlovi vrátiti podle práva. Ibidem.

80 Cf. text of the Art. 478 of the Law Book of the City of Brno: Quia in nostra civitate secundum approbatam ab antiquo consuetudinem servamus, quod pro ludo seu debito ludi nullam alicui iusticiam exhibemus, attamen rigore iuris exigente, quia littere vestre dicunt unum de scabinis ludo tamquam computantem et numerantem affuisse et nobili bina vice iniuriam factam esse considerasse et hospitem super nobilem conspirasse et occulte tenuisse et gepotes vulgaliter dicendo gepot posuisse, bene consonat iusticie, quod nobilis ad solucionem pecunie taliter deluse nullatenus teneatur. Právní kniha ..., I, p. 306. Roman law prohibited not only judicial enforcement arising from gambling and betting but during the reign of Justinian I. it applied also to a game itself. Cf. C. 3.41.3.1: Commodis igitur subiectorum providere cupientes hac generali lege decernimus, ut nulli liceat in privatis seu publicis locis ludere neque in specie neque in genere: et si contra factum fuerit, nulla sequatur condemnatio, sed solutum reddatur et competentibus actionibus repetatur ab his qui dederunt vel eorum heredibus aut his neglegentibus a patribus seu defensoribus locorum [...]. Briefly from literature see also M. Boháček, Římské právní prvky..., p. 15 (natural obligations).

81 Legal instruction No. 28. Cf. text of the finding: Quod in ludis taxillorum iure nostro nullum penitus ius facimus nec damus. Et ideo iudici, nisi ludus taxillorum sub aliqua pena generaliter interdictus esset, nullam partem lucri adiudicamus. Nálezy brněnského městského práva..., p. 22. 


\subsubsection{Procedural status of the parties}

The last case discussed in the essay is recorded in Liber negotiorum and concerns the procedural status of the parties. The text of a legal instruction is related to the dispute between two parties, the plaintiff (pledge creditor) and the defendant (pledge debtor). ${ }^{82}$ The subject of the pledge was a pig, which represented the claim on money of the plaintiff. The councillors of Uherské Hradište turned to Brno with the question who should be heard first, whether the plaintiff or the defendant. The sworn men of Brno decided in accordance with the Roman law principle In pari causa melior est conditio possidentis (D. 50.17.128), which served as a direct argument in the text of the finding. ${ }^{83}$ It is one the few cases when the sworn men quoted the original wording of the applied Roman law regulation. The aforementioned principle thus expressed a more favorable position of the holder (possessor), in this case the pledge holder, who had the right to testify first. Although the principle is stated in Arts. 470 par. c) and 549 of the Law Book of the City of Brno ${ }^{84}$ it should be stressed that in this case the sworn men of Brno proceeded from another source, probably from the manuscript of Digest, which at that time was available at the library of the city chancery. It was a copy of the last two titles of the fiftieth Digest book called De regulis iuris et de verborum significatio. Although the manuscript did not survive, its content was documented in the aforementioned Manipulus vel directorium iuris civilis from the 1380 s, whose author was the Brno notary of that time, Jan of Gelnhausen. Manipulus, which represents the first ever legal monument directly following the tradition of the Law Book of the City of Brno contains hundreds of definitions and regulations adopted directly from the aforementioned volume of Digest. This Roman law principle is formulated in Arts. 1186 and 1188 of the Manipulus,${ }^{85}$ which represented a general interpretative guide. However, the subject of our interest is also the aforementioned Art. 470 of the Law Book of the City of Brno in the section De iuratis dealing with the office of sworn men. It is the regulation with the section De iuratis eorum et auctoritate et ipsorum statutis et sentenciis related to the work content of sworn men, namely the issuing of findings and legal instructions. In par. c) of the particular regulation it is stated that in all cases when it is not clear who is right, whether the plaintiff or the complainant, the decision is always made in favor of the holder. The fact that the scribe Jan included this regulation not only in the section related to the security interests (see the aforementioned Art. 549 of the Law Book of the City of Brno), where it belongs the-

82 Legal instruction No. 54. Ibidem, p. 39.

83 The existence of this principle was already pointed out by M. Flodr in the edition commentary (p. 102). Cf. text of the legal instruction: Casum vestrum nobis propositum de quibusdam porcis plene intelleximus diffinitive respondentes, quod ille, qui eosdem porcos in sua tenet potestate et demonstrare ac probare intendit eos emisse, maius ius habet in probando et obtinendo porcos quam alter, qui dicit contrarium, quia melior est condicio possidentis quam impetentis in hoc casu. Nálezy brněnského městského práva..., p. 39.

84 See Art. 470 of the Law Book of the City of Brno: Item, si obsura sunt iura possidentis et petentis, tunc sentenciandum est pro possident. And also Art. 549: Sentenciatum est, quod possessor pignoris potest melius in cruce iurando super pignore debitum suum obtinere, quam pignus possit sibi per partem contrariam decertari. Právni kniha..., I, pp. 300 and 336.

85 Cf. Art. 1186: Quando de lucro duorum queratur, melior est causa possidentis. And further Art. 1188: In pari causa possessor pocior haberi debet. Jan z Gelnhausenu..., p. 180. 
matically, is another practical evidence that Jan interpreted the Roman law as common law, i.e. the law applied in cases where domestic law was not able to solve the dispute.

\section{Conclusion}

The essay focused on the issue of the relation of the earliest law books of the city of Brno to legal practice implemented on the territory of the Brno legal circle. The introduction offered an overview of the development of Brno municipal law until the midfourteenth century and pointed out the exceptional position of the Law Book of Jan the Notary. It is known that Brno had a very elaborate legal system for its time, which later became a source of inspiration not only for towns belonging to its jurisdiction but also for localities outside the Brno legal circle. It concerns particularly the Law Book of the City of Brno, which may be considered the main source of Brno municipal law, despite not having been codified and lacking a normative character. Nevertheless, this fact did not necessarily mean that the legal regulations contained here served only as recommendation and was not enforceable in practice. Such a speculation would be true in the current legal situation, when the state, in the spirit of a modern legal theory, guarantees to the recipients of legal regulations that only normative legal acts which are the result of the standard legal process will be legally enforceable. However, this was not the case in the past, when the condition for the enforceability of a particular legal norm was not the existence of a generally binding nature declared by the state authority, but a social acceptance and a long-term use in practice. The absence of a normative element in Brno municipal books was balanced by the existence of royal privileges, which possessed the highest legal power, and therefore were applicable with priority. The logical consequence of this provision was the fact that law books were created in accordance with the legislation of privileges. This was to avoid the mutual conflict, which would have made the applicability of legal books impossible and the primary function of this type of source would have lost any relevance.

The fact that the Brno law books were intended for legal practice is proven also by the gradual acquisition of their redactions, modified for the needs of the particular period. In the same way, translations of law books originally written in Latin, created at the time when Latin as the official language was receding in favour of Czech and German, were not made for their own sake. Nevertheless, an important evidence of the relation of law books and legal practice of the period is provided mainly by sources arising from the activities of the municipal court deciding the disputes, which belonged to its jurisdiction, or from the activities of the municipal council, which issued legal instructions for the localities in the Brno legal circle. As may be inferred from the analyses of several legal instructions for Uherské Hradiště, instructions of the sworn men of Brno corresponded to the legislation of the Law Book of the City of Brno and the regulations based on the ius commune. The fact that the sworn men of Brno issued their legal instructions in accordance with the Law Book of the City of Brno gives evidence of the significant role of this source in legal practice of the Brno legal circle. It confirms the findings of the earlier literature that this source was not of a theoretical nature but was intended for practical 
application. However, it would be wrong to assume that the sworn men used only this source without considering other sources. As was previously stated in the essay, the source base of Brno municipal law consisted not only of law books, but also of granted privileges and town statutes, and other sources, which formed the so-called subsidiary law. It was this law that represented an important set of standards applicable where the domestic legislation seemed insufficient. Therefore, it seems logical that the Brno City council acquired copies of foreign laws, which served not only as a source of inspiration for the formation of law, but also played an important role in the application practice of the city council and the municipal court. It is likely that the sworn men of Brno used this alternative material even in cases where the Law book of the City of Brno could offer an adequate solution. This is clear from the aforementioned analysis of the particular legal instruction related to the procedural status of the parties. It was discovered that the sworn men formulated their instruction on the basis of the manuscript of Digest, which was available at that time, and not on the basis of the Law Book of the City of Brno, although it contained the relevant regulation. This finding is based on a comparison of the particular legal provision in the Law Book of the City of Brno and in Brno Manipulus that contains the content of the lost manuscript of Digest.

Considering that the essay dealt with a relatively small sample of cases, it is not possible to generalize these findings and state that the legal practice of the city of Brno was without any exceptions governed by the Law Book of the City of Brno. In the same way, it is not possible to relate findings concerning the presence of the ius commune principles in the selected legal instructions to the applied practice of Brno as a whole and believe that it was the case in all situations. Nevertheless, the purpose of this analysis was to contribute at least partially to understanding the legal practice of the city of Brno, which the literature has not targeted sufficiently so far, despite the fact that Brno legal instructions offer an interesting potential not only for legal-historical research, but also for the history of everyday life of medieval and early modern Moravia. Therefore, there is chance that this type of source might in future become the subject of interest not only for lawyers and legal Romanists but also historians and philologists.

\section{Bibliography}

\section{Sources}

Codex diplomaticus et epistolaris Moraviae VI, ed. J. Chytil, Brünn 1854; VIII, ed. V. Brandl, Brünn 1874.

Codex diplomaticus et epistolaris regni Bohemiae, IV-1, ed. J. Šebánek, S. Dušková, Pragae 1962; V-1, ed. J. Šebánek, S. Dušková, Pragae 1974.

Codex iuris Bohemici. Tomus primus, aetatem přemyslidarum continens, ed. H. Jireček, Pragae 1867.

Iura originalia civitatis Brunensis. Privilegium českého krále Václava I. z ledna roku 1243 pro město Brno, ed. M. Flodr, Brno 1993.

Jan z Gelnhausenu. Přrručka práva městského: (Manipulus vel directorium iuris civilis), ed. M. Flodr, Brno 2008.

Artykuły - Articles 
Liber informationum et sententiarum čili Naučeni Brněnská Hradišt'ské městské radě dávaná od roku 1447 až do roku 1509 s dodatky do roku 1540, ed. I. Tkáč, Uherské Hradiště 1882.

Nálezy brněnského městského práva. Svazek I. (-1389), ed. M. Flodr, Brno 2007.

Nejstarši uherskohradištská městská kniha. Liber negotiorum civitatis Hradisch, ed. M. Čoupková, Uherské Hradiště 2001.

Právní kniha města Brna. I-III, ed. M. Flodr, Brno 1990-1993.

Urkundenbuch zur Geschichte der Babenberger in Österreich, 1-2, ed. H. Fichtenau, Wien 1950, 1955.

\section{Monographs}

Bellomo M., Europäische Rechtseinheit. Grundlagen und System des Ius Commune, München 2005.

Bellomo M., The Common Legal Past of Europe: 1000-1800. Washington, DC 1995.

Bily I., Carls W., Gönczi K., Lazar M., Sächsisch-magdeburgisches Recht in Tschechien und in der Slowakei. Untersuchungen zur Geschichte des Rechts und seiner Sprache, in printing (= IVS SAXONICO-MAIDEBVRGENSE IN ORIENTE, 5)

Boháček M., Das Römische Recht in der Praxis der Kirchengerichte der böhmischen Ländern im XIII. Jahrhundert, "Studia Gratiana" 1967, vol. 11.

Boháček M., Einflüsse des Römischen Rechts in Böhmen und Mähren, Mediolani 1975.

Boháček M., Ještě k ř́mskoprávnímu obsahu brněnské právní knihy [in:] Sborník prací z dějin práva československého, sv. I. (K 50. narozeninám profesora Jana Kaprasa jeho žáci), Praha 1930.

Boháček M., Řimské právní prvky v právní knize brněnského písaře Jana, Zvl. otisk práce ze semináře Českého práva na Karlově univerzitě v Praze (no. 9), Praha 1924.

Boháček M., Řimské právo v listinné praxi českých zemí 12.-15. století, „Sborník archivních prací" 1974, vol. 24, no. 2.

Boháček M., Řimské právo v právním vývoji českých zemí [in:] Antika a česká kultura, ed. L. Svoboda, Praha 1978.

Burger G., Die südwestdeutschen Stadtschreiber im Mittelalter, Böblingen 1960.

Coing H., Handbuch der Quellen und Literatur der neueren europäischen Privatrechtsgeschichte, I: Mittelalter (1100-1500). Die gelehrten Rechte und die Gesetzgebung, München 1973.

Čáda F., Sententia Brunnensie 536 [in:] Sborník k poctě šedesátých narozenin Jaroslava Kallaba, ed. K. Engliš, Praha 1939.

Černý M., Ius commune a ius proprium ve středověku [in:] Metamorfózy práva ve střední Evropě IV: žijeme v nejlepším z možných právních světů?, ed. F. Cvrček, Helena Jermanová, Plzeň 2015.

Čoupková M., Nejstarši uherskohradištská městská kniha. Liber negotiorum civitatis Hradisch [in:] Středověká města na Moravě a v sousednich zemích, eds. P. Futák, M. Plaček, M. Vařeka, Hodonín 2009.

Dějiny Brna 2. Středověké město, ed. L. Jan, Brno 2013.

Dějiny města Brna 1, eds. J. Dřímal, V. Peša, Brno 1969.

Doležel J., Tišnov a Tišnovští v právní knize města Brna z poloviny 14. století, „Sborník Okresního muzea Brno - venkov" 2000.

Flodr M., Brněnské městské právo na konci středověku (1389-konec 15. století), Brno 2008.

Flodr M., Brněnské městské právo po smrti notáře Jana (1359-1389), Brno 2006.

Flodr M., Brněnské městské právo. Zakladatelské období (-1359), Brno 2001.

Flodr M., Cesta k právu a spravedlnosti. Jan, notář města Brna [in:] Osobnosti moravských dějin, eds. L. Jan et al., Brno 2006. 
Gelehrte im Reich zur Sozial- und Wirkungsgeschichte akademischer Eliten des 14. bis 16. Jahrhunderts, ed. R. Ch. Schwinges, Berlin 1996.

Grossi P., A History of European Law, Malden 2010

Haněl J., O vlivu práva německého v Čechách a na Moravě, Praha 1874.

Hoffmann F., Brněnské městské právo [in:] Brno mezi městy střední Evropy (Sborník projevů, studií, úvah a sdělení zvědeckého sympozia konaného 29.-30. listopadu 1979, eds. F. Zřídkaveselý, V. Peša, Brno 1983, pp. 166-180.

Hoffmann F., Soupis rukopisů městských práv v českých zemích [in:] Městské právo v 16.-18. století v Evropě. Sborník př́spěvkủ z mezinárodni konference uspořádané Právnickou fakultou UK ve dnech 25.-27. záŕi 1979 v Praze, ed. K. Malý, Praha 1982.

Isenmann E., Die deutsche Stadt im Mittelalter (1150-1550), Wien-Köln-Weimar 2014.

Janiš D., Městská správa a soudnictví [in:] Dějiny Brna 2. Středověké město, ed. L. Jan, Brno 2013.

Janiš D., Úřad rychtáře a městská jurisdikce v Brně ve 13. a 14. století. 2. část, obdobi rozvoje města, „Brno v minulosti a dnes” 2013, vol. 26.

Jordánková H., Sulitková L., Fungováni nejvyššiho městského správniho orgánu ve světle pamětních zápisủ městských písař̉u na př́kladu raně novověkého Brna [in:] Pragmatické písemnosti v kontextu právním a správním, eds. Z. Hojda, H. Pátková, Praha 2008.

Kluge M.F., Die Macht des Gedächtnisses: Entstehung und Wandel kommunaler Schriftkultur im spätmittelalterlichen Augsburg, Leiden-Boston 2014.

Koschaker P., Europa und das römische Recht, 4. Aufl., München 1966.

Krška I., Brněnská právní naučení Uherskému Hradišti ve druhé polovině 14. století, „Brno v minulosti a dnes“ 1962, vol. 4.

Lange H., Kriechbaum M., Römisches Recht im Mittelalter, Bd. I: Glossatoren, München 1997.

Lange H., Kriechbaum M., Römisches Recht im Mittelalter, Bd. II: Kommentatoren, München 2007.

Malárová L., Zásada "bonae fidei" a institut nabytí věci od nevlastnika v Př́ručce práva městského Jana z Gelnhausenu [in:] Cofola 2011, eds. E. Žatecká, L. Kováčová, J. Horecký, V. Omáčka, Brno 2011.

Mareš J., Magdeburské právo ve městech severozápadnich Čech v predhusitské době, defended at the Faculty of Arts of Charles University in Prague in 2008.

Mayer M.A., Der Kauf nach dem Augsburger Stadtrecht von 1276 im Vergleich zum gemeinen römischen Recht, Berlin 2009.

Mendl B., Tak řě̌ené Norimberské právo v Čechách, Praha 1938.

Město a intelektuálové od středověku do roku 1848: Sborník statí a rozšírených přispěvků z 25. vědecké konference Archivu hlavního města Prahy, uspořádané ve spolupráci s Institutem mezinárodních studií Fakulty sociálnich věd Univerzity Karlovy v Praze ve dnech 10. až 12. ř́jna 2006 v Clam-Gallasově paláci v Praze, eds. O. Fejtová, V. Ledvinka, J. Pešek, Praha 2008.

Nový R., Městské knihy v Čechách a na Moravě, 1310-1526: Katalog, Praha 1963.

Pamětni kniha města Brna z let 1343-1376 (1379), ed. M. Flodr, Brno 2005.

Právní kniha města Brna. II. Komentár̆, ed. M. Flodr, Brno 1992.

Repgen T., Ius Commune [in:] Usus modernus pandectarum. Römisches Recht, Deutsches Recht und Naturrecht in der Frühen Neuzeit, eds. H. P. Haferkamp, T. Repgen, Köln-Weimar-Wien 2007.

Rössler E.F., Die Stadtrechte von Brünn aus dem XIII. u. XIV. Jahrhundert, nach bisher ungedruckten Handschriften, Prag 1852.

Rössler E.F., Über die Bedeutung und Behandlung der Geschichte des Rechts in Österreich, Prag 1847.

Schubart-Fikentscher G., Das Brünner Schöffenbuch. Beiträge zur spätmittelalterlichen Rechts-und Kulturgeschichte, „Deutsches Archiv” 1937, vol. 1. 
Schubart-Fikentscher G., Das Eherecht im Brünner Schöffenbuch, Stuttgart 1935.

Schubart-Fikentscher G., Die Verbreitung der deutschen Stadtrechte in Osteuropa, Weimar 1942.

Schubart-Fikentscher G., Neue Fälle zum Brünner Recht, „Deutsches Archiv” 1939, vol. 3.

Schubart-Fikentscher G., Römisches Recht im Brünner Schöffenbuch. Ein Betrag zur Rezeptionsgeschichte, „Zeitschrift der Savigny-Stiftung für Rechtsgeschichte. Germanistische Abteilung" 1947, vol. 65.

Schwabenspiegel-Forschung im Donaugebiet. Konferenzbeiträge in Szeged zum mittelalterlichen Rechtstransfer deutscher Spiegel, ed. E. Balogh, Berlin-Boston 2015.

Sulitková L., Městské úřední knihy z Archivu města Brna, 1343-1619: Katalog. 4 vol., Brno 1998-2003.

Sulitková L., Vývoj městských knih v Brně ve středověku: (v kontextu vývoje městských knih $v$ českých zemích), Praha 2004

Šmídová Malárová L., „Causa legittimae absentiae” a její ř́mskoprávní základ v naučeních brněnského městského práva pro Uherské Hradiště [in:] Datum per manus. Přátelé, kolegové a žáci Zbyňku Svitákovi k 60. narozeninám, ed. L. Führer, I. Musilová, J. Voborný, R. Červená, Brno 2015.

Šmídová Malárová L., K významu právnich naučení města Brna z perspektivy právní romanistiky [in:] Bibliotheca antiqua 2015. Sbornik z 24. konference dne 4.-5. listopadu 2015, eds. R. Krušinský, T. Vintrová, Olomouc 2015.

Štachová N., Inspirační zdroje Koldinových Práv městských. Výzvy kodikologie české romanisti$c e$, „Časopis pro právní vědu a praxi” 2013, vol. 21 (supplementum).

Štachová N., Law of Obligations in Light of the Bohemian Diplomatic Documents of the Thirteenth Century, „Journal on European History of Law” 2011, vol. 2, no. 2.

Štachová N., Obligační právo ve světle českého diplomatického materiálu 13. století [in:] Naděje právní vědy. Býkov 2010, ed. V. Knoll, Plzeň 2011.

Štarha I., Naučení brněnského městského práva v 16. a poč. 17. stol., „Folia diplomatica” 19561957, vol. 5.

Štarha I., Okruh brněnského městského práva [in:] Brno mezi městy středni Evropy - Sborník projevů, studií, úvah a sdělení z vědeckého sympozia konaného 29.-30. listopadu 1979, eds. F. Zř́́dkaveselý, V. Peša, Brno 1983.

Štarha I., Okruh brněnského městského práva v době předbělohorské, „Brno v minulosti a dnes” 1966, vol. 8

Štarha I., Právni naučeni brněnského městského práva v době predbělohorské (Dissertation), Brno 1970.

Štěpán J., Ke krystalizačnímu procesu městského práva českého [in:] Městské právo v 16.-18. století v Evropě. Sbornik príspěvkỉ z mezinárodni konference uspořádané Právnickou fakultou UK ve dnech 25.-27. záŕi 1979 v Praze, ed. K. Malý, Praha 1982.

The Creation of the Ius Commune: From Casus to Regula, eds. J.W. Cairns, P.J. du Plessis, Edinburg 2010.

Trusen W., Anfänge des gelehrten Rechts in Deutschland. Ein Beitrag zur Geschichte der Frührezeption, Wiesbaden 1962.

Uses of the Written Word in Medieval Towns: Medieval Urban Literacy II, eds. M. Mostert, A. Adamska, Turnhout 2014.

Vermouzek R., Brno - křižovatka starých cest [in:] Brno mezi městy střední Evropy - Sborník projevů, studií, úvah a sdělení z védeckého sympozia konaného 29. - 30. listopadu 1979, eds. F. Zřídkaveselý, V. Peša, Brno 1983.

Writing and the Administration of Medieval Towns: Medieval Urban Literacy I, eds. M. Mostert, A. Adamska, Turnhout 2014. 